\title{
NAPONI I DEFORMACIJE U KOLOVOZNIM KONSTRUKCIJAMA USLED DEJSTVA TEMPERATURE
}

Mila Svilar, dipl.građ.inž. ${ }^{1}$

Doc. dr Igor Jokanović, dipl.građ.inž. ${ }^{2}$

UDK: $625: 624.042 .5$

DOI: 10.14415/zbornikGFS30.07

Rezime: Naponi usled dejstva temperature u kolovoznim konstrukcijama, naročito krutim, po svom apsolutnom iznosu, su često istog reda veličine kao i od opterécenja od vozila, a dešava se $i$ da usled takvih uticaja mnoge ploče ispucaju pre nego što je put predat u saobraćaj. Temperaturni naponi koji nastaju u kolovoznim konstrukcijama obuhvataju napone usled savijanja i izvijanja, napone pri trenju i pritajene napone. Naponi koji su izazvani dejstvom temperature u kolovoznoj konstrukciji tokom dana su uglavnom ispod čvrstoće upotrebljenih materijala tako da se ne javljaju posledice po konstrukciju. Međutim, dolazi do pojave zaostalih napona čijom akumulacijom posle dovoljno dugog vremenskog perioda može doći do pojave loma u konstrukciji, odnosno termičkog zamora materijala. U radu se prikazuje uticaj temperaturnih promena na kolovozne konstrukcije u fizičkom i mehaničkom smislu, te način na koji se temperatura uzima u obzir prilikom dimenzionisanja kolovoznih konstrukcija.

Ključne reči: kolovozna konstrukcija, temperatura, temperaturni naponi, dimenzionisanje

\section{UVOD}

Materijali od kojih su izgrađene kolovozne konstrukcije se različito zagrevaju i hlade. Spoljni faktori koji utiču na temperaturu slojeva i na ponašanje materijala proističu iz klimatskih karakteristika, a manifestuju se preko temperature vazduha, sunčane radijacije i vetra. Spoljni faktori su prvenstveno zavisni od geografske lokacije na kojoj se nalazi izgrađena kolovozna konstrukcija.

Unutrašnji faktori uticaja na kolovozne konstrukcije obuhvataju emitovanje velikih talasa radijacije iz tla i termička svojstva materijala kolovozne konstrukcije i posteljice. Oni su zavisni od geološke građe terena. U odnosu na spoljne faktore, koji mogu biti promenljivi, unutrašnji se za određenu lokaciju mogu smatrati približno stalnim.

Od spoljnih faktora najveći uticaj ima temperatura vazduha, ali i sunčana radijacija u određenim slučajevima značajno utiče na temperaturu na površini i u unutrašnjosti kolovozne konstrukcije. Istraživanja su pokazala da je temperatura na površini asfaltnog

\footnotetext{
${ }^{1}$ Univerzitet u Novom Sadu, Građevinski fakultet Subotica, Kozaračka 2a, Subotica, Republika Srbija, e-mail: svilarm@gf.uns.ac.rs

2 Univerzitet u Novom Sadu, Građevinski fakultet Subotica, Kozaračka 2a, Subotica, Republika Srbija, e-mail: jokanovici@gf.uns.ac.rs
} 
zastora kolovozne konstrukcije uglavnom viša od temperature vazduha. Razlog tome je sunčana radijacija, odnosno upijanje toplote $u$ crnu površinu asfalta.

Temperatura utiče na mehanička i reološka svojstva svih materijala u kolovoznoj konstrukciji, pri čemu je najveći uticaj izražen na asfaltne slojeve. Asfalt je materijal koji na visokim temperaturama ima visokoelastične karakteristike, a na niskim visokoplastične. Ponašanje asfalta se može predstaviti određenim reološkim modelima koji se sastoje od različito povezanih Njutnovih i Hukovih elemenata (amortizera i opruga) (Slika 1). Pri visokim temperaturama dolaze do većeg izražaja Njutnovi elementi tj. tečenje, a pri niskim temperaturama Hukovi elementi, tj. plastičnost.[1]

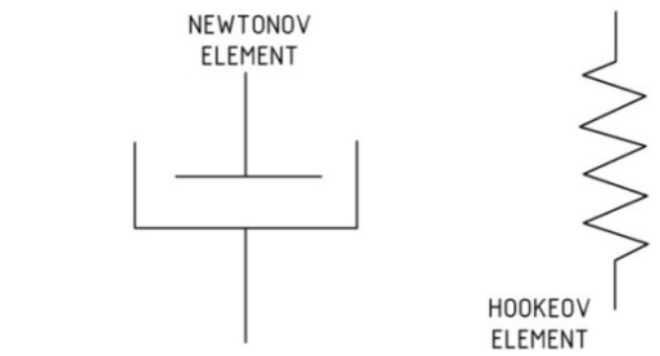

Slika 1. Osnovni reološki modeli ponašanja asfalta [1]

\section{PRODIRANJE MRAZA KROZ KOLOVOZNU KONSTRUKCIJU}

Problem smrzavanja kolovozne konstrukcije i tla ispod nje je već dugo predmet intezivnog proučavanja, praktično od nastanka modernih kolovoznih konstrukcija. Prvo se smatralo da glavne neprilike sa smrzavanjem na putevima dolaze zbog povećanja zapremine leda u odnosu na zapreminu vode pošto se prilikom pretvaranja vode u led javlja povećanje zapremine od oko $9 \%$. Međutim, u stvarnosti obično nastaje dosta veće izdizanje nego što bi se to moglo pripisati pomenutoj razlici zapremine [1]. Sondiranjem smrznutih i izdignutih kolovoznih konstrukcija utvrđeno je da se i u posteljici, ukoliko se sastoji od materijala osetljivih na smrzavanje, nalazi velika količina leda u obliku ledenih sočiva (Slika 2).

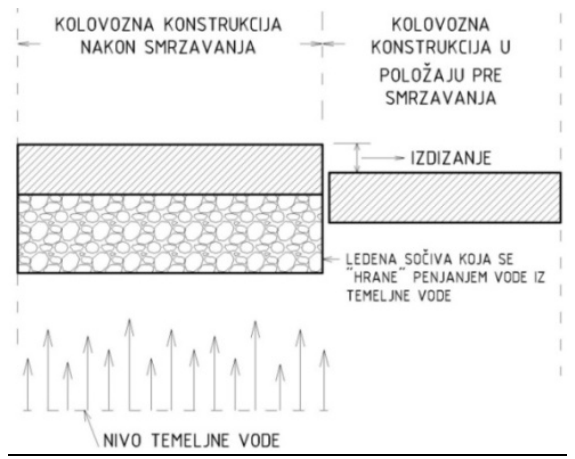

Slika 2. Izdizanje kolovozne konstrukcije usled stvaranja ,,ledenih sočiva“ [1]

74 | JOURNAL OF FACULTY OF CIVIL ENGINEERING 30 (2016) | 
Da bi se u tlu razvila ledena sočiva, moraju biti ispunjena tri uslova:

- dovoljno niska temperatura da se voda u tlu počne smrzavati;

- mogućnost doticanja vode u zonu smrzavanja;

- tlo u zoni smrzavanja mora biti osetljivo na smrzavanje.

Svaka čestica tla je okružena filmom absorbovane vode. Pri smrzavanju dolazi do privlačenja tog filma sa gornje strane i uključivanja vode u smrznuti ledeni kristal. Zbog toga što se film vode drži uz česticu tla jakim molekularnim silama, on traži uspostavljanje ravnoteže i privlači vodu odozdo. Ledena sočiva se pri tome potiskuju naviše i tako dolazi do izdizanja. Lomovi kolovozne konstrukcije nastaju usled dejstva zamora (posledica saobraćajnog opterećenja, ponavljanja temperaturnih ciklusa), dejstva ledenih sočiva u kolovoznoj konstrukciji, reflektovanja pukotina ispod kolovozne konstrukcije i usled delovanja niskih temperatura.Termičkim dejstvom izazvani lomovi u fleksibilnoj konstrukciji su problem, kako u klimatskim područjima sa niskim temperaturama, tako i u klimatskim zonama gde je primetno veliko variranje dnevnih temperatura [2]. Usled dejstva niskih temperatura, termički naponi bivaju izjednačeni sa čvrstoćom pri zatezanju materijala od kojih je kolovoz sačinjen. Na taj način dolazi do kidanja veza unutar samog bitumena i veza između bitumena i agregata - loma konstrukcije. Temperatura loma je grafički prikazana na Slici 3.

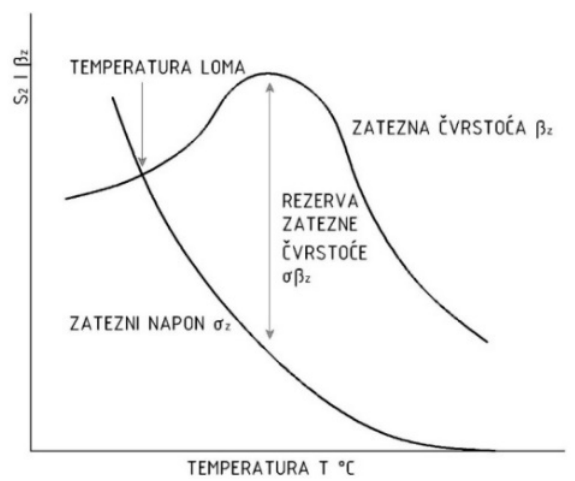

Slika 3. Određivanje čvrstoće pri zatezanju u zavisnosti od temperature [2]

\section{NAPONI I DEFORMACIJE U KOLOVOZNIM KONSTRUKCIJAMA IZAZVANI TEMPERATURNIM PROMENAMA}

Naponi od temperature kod krutih kolovoznih konstrukcija se razvrstavaju u tri kategorije:

(i) naponi pri savijanju ili izvijanju, koji nastaju usled razlike u temperaturama na površini i dnu betonske ploče ili različite vlažnosti na površini i dnu ploče;

(ii) naponi pri trenju, nastali zbog promene temperature u betonskoj ploči i podlozi;

(iii) pritajeni naponi, koji su nastali usled uklještenja ploča, čime je sprečeno njihovo slobodno širenje, zbog toga što se spojnice ispunjavaju neodgovarajućim materijalom ili zbog pojave pumpanja.

Kod fleksibilnih kolovoznih konstrukcija uticaj temperature se manifestuje dvojako, i to preko: 
(i) izuzetno velike zavisnosti modula krutosti - elastičnosti od temperature, odnosno promenljive nosivosti u toku različitih godišnjih doba;

(ii) izuzetno male zavisnosti kolovozne konstrukcije (temperaturnih napona) od promene temperature.

U svakom slučaju uticaj temperature na napone u krutim kolovoznim konstrukcijama je znatno veći [3].

\subsection{Naponi pri savijanju betonske ploče}

Naponi savijanja variraju usled temperaturnih razlika između vrha i dna ploče (Slika 4). Ako merenjima nije drugačije dokazano, može se očekivati maksimalni temperaturni gradijent od 0,055 do $0,077^{\circ} \mathrm{C} / \mathrm{mm}$ tokom dana i oko polovine ove vrednosti tokom noći.
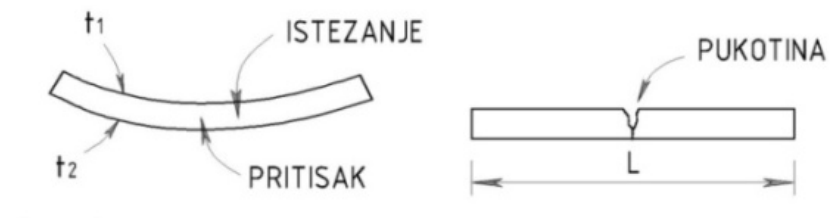

$t_{1}<t_{2}$

Slika 4. Savijanje betonske ploče [3]

Ispitivanja su pokazala da se maksimalna temperaturna razlika između gornje i donje površine ploče javlja tokom aprila i maja, kada se javlja i najveći broj savijanja tokom godine [4]. Merenjima je utvrđeno i da temperaturna razlika nije proporcionalna debljini ploče; brža promena debljine ploče, znatno sporija promena temperaturna razlika za određenu debljinu ploče. Veći temperaturni gradijenti se upotrebljavaju kod tanjih ploča. $\mathrm{Na}$ osnovu radova Vestergarda i Bredberia obrasci za proračun napona pri savijanju ili izvijanju glase [3]:

na ivici ploče

$$
\sigma=\frac{\alpha \cdot E \cdot \Delta t}{2} \cdot C
$$

unutar ploče

$$
\sigma=\frac{\alpha \cdot E \cdot \Delta t}{2 \cdot\left(1-v^{2}\right)}\left(C_{1}+v \cdot C_{2}\right)
$$

gde je:

$\alpha \quad$ koeficijent termičkog širenja betona $\left(7 \cdot 10^{-6} \mathrm{~cm} /{ }^{\circ} \mathrm{C}\right)$;

E modul elastičnosti betona $\left[\mathrm{MN} / \mathrm{m}^{2}\right]$;

$v \quad$ Poasonov koeficijent;

$\mathrm{L}_{\mathrm{x}}, \mathrm{L}_{\mathrm{y}} \quad$ odgovarajuća slobodna dužina ili širina ploče [m];

$\mathrm{C}_{1} \quad$ koeficijent za pravac u kome se traži napon pri savijanju (Slika 5);

$\mathrm{C}_{2} \quad$ koeficijent za upravan pravac (Slika 5);

$\Delta \mathrm{t} \quad$ razlika u temperaturama na vrhu i dnu ploče $\left[{ }^{\circ} \mathrm{C}\right]$;

l radijus relativne krutosti $l=\sqrt[4]{\frac{E \cdot h^{3}}{12\left(1-v^{2}\right) K}}[\mathrm{~m}]$. 


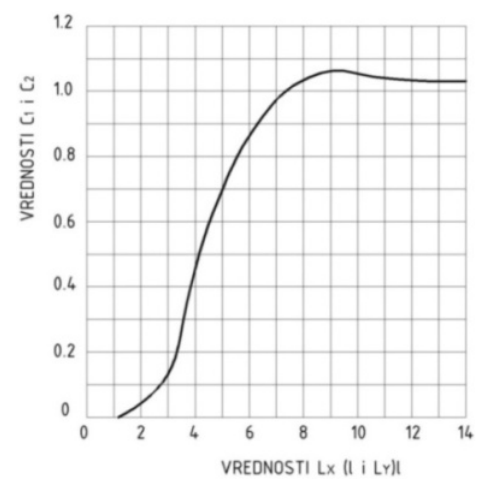

Slika 5. Koeficijent za određivanje napona pri savijanju [3]

\subsection{Naponi pri trenju betonske ploče}

Ukoliko sile stvorene skupljanjem ili širenjem ploče prekorače čvrstoću na pritisak ili zatezanje betona dolazi do stvaranja pukotina u betonskim pločama. Do pukotina može doći čak i pri prvom hlađenju ili zagrevanju betonskog vrlo mladog kolovoza, ako su ispunjeni kritični uslovi. Sila trenja $F=f \cdot W$ se može predstaviti kao proizvod napona $\sigma$ i poprečnog preseka ploče $A=D \cdot \omega$, a normalna sila kao $W=D \cdot \omega \cdot L \cdot \gamma_{m}$, pa se dobija izraz [3]:

$$
\sigma \cdot D \cdot W=\gamma_{m} \cdot D \cdot W \cdot L \cdot f
$$

gde je:

F podužna sila [MN];

f koeficijent trenja između ploče i podloge (Tabela 1);

W normalna sila (ili masa ploče) $[\mathrm{MN}]$;

D visina ploče $[\mathrm{m}]$;

$\omega \quad$ širina ploče [m];

L dužina ploče [m];

$\gamma_{\mathrm{m}} \quad$ zapreminska masa $\left[\mathrm{MN} / \mathrm{m}^{3}\right]$.

Time se dobija izraz za određivanje napona pri trenju betonske ploče u obliku:

$$
\sigma=\gamma_{m} \cdot L \cdot f
$$

Tabela 1. Koeficijent trenja na kontaktu između betonske ploče i podloge [3]

\begin{tabular}{|l|c|}
\hline \multicolumn{1}{|c|}{ tip podloge } & koeficijent trenja \\
\hline površinska obrada & 2,2 \\
stabilizacija bitumenom & 1,8 \\
stabilizacija cementom & 1,8 \\
šljunkovito-peskovit agregat & 1,5 \\
drobljeni agregat & 1,5 \\
pesak & 1,2 \\
prirodna posteljica & 0,9 \\
\hline
\end{tabular}




\section{3. Širenje ploča}

Da bi došlo do loma napon na zatezanje mora dostići kričnu vrednost, i to [3]:

$$
\sigma=E \cdot \alpha \cdot \Delta t=35.000 \cdot 10 \cdot 10^{-6} \cdot 29=10,15 \mathrm{MN} / \mathrm{m}^{2}
$$

gde je:

$\sigma \quad$ napon u betonu kome nije ostavljen prostor za širenje $\left[\mathrm{MN} / \mathrm{m}^{2}\right]$;

$\alpha \quad$ koficijent linearne termičke dilatacije (Tabela 2);

$\Delta \mathrm{t} \quad$ razlika u temperaturamatokomperioda posmatranja $\left[{ }^{\circ} \mathrm{C}\right]$.

\section{Tabela 2. Uticaj tipa agregata na koeficijent termičkog širenja betona [3]}

\begin{tabular}{|l|c|c|}
\hline \multirow{2}{*}{ agregat } & koeficijent termičkog širenja $\alpha\left(\mathrm{po}{ }^{\circ} \mathrm{C} \cdot 10^{-6}\right)$ \\
\cline { 2 - 3 } & opseg & srednja vrednost \\
\hline kvarcit & $11,7-14,6$ & 13,2 \\
kvarc & $9,0-13,2$ & 11,1 \\
peščar & $9,2-13,3$ & 11,3 \\
mermer & $4,1-7,4$ & 5,8 \\
silikatni krečnjak & $8,1-11,0$ & 9,6 \\
granit & $8,1-10,3$ & 9,2 \\
bazalt & $7,9-10,4$ & 9,2 \\
krečnjak & $4,2-10,3$ & 7,3 \\
šljunak & $9,0-13,7$ & 11,4 \\
\hline \multicolumn{2}{|c|}{} \\
\hline
\end{tabular}

Iz napred navedenog se zaključuje da je najveći napon pri pritisku usled širenja betonske ploče znatno manji od čvrstoće na pritisak. Po engleskim propisima [5] najmanja čvrstoća na pritisak betona za puteve, usled širenja betonske ploče koja je minimalne debljine $15 \mathrm{~cm}$, posle 28 dana iznosi $27,6 \mathrm{MN} / \mathrm{m}^{2}$. U praksi je čest slučaj da čvrstoća na pritisak u proseku iznosi oko $40 \mathrm{MN} / \mathrm{m}^{2}$. Do izdizanja kolovoza može doći samo pri ekstremnim temperaturama i pogrešno postavljenim spojnicama.

U klimatskim uslovima koji su slični našim, važi princip da se ekspanzione spojnice obavezno grade u periodu od oktobra do aprila. U letnjem periodu, kada je razlika između temperature ugrađivanja i najtoplijeg dela godine manja od $10^{\circ} \mathrm{C}$, napon pri pritisku je manji od 3,5 MPa. Prema tome, pošto ne postoji rizik od izdizanja ploča, ekspazione spojnice mogu biti izostavljene [3].

\subsection{Skupljanje ploča}

Tokom skupljanja ploča nastaju naponi zatezanja usled trenja između ploče i podloge (Slika 6). Na Slici 6. je prikazan i smer delovanja napona pri skupljanju ploče, a sračunava se prema izrazu:

$$
\sigma=\gamma_{m} \cdot \frac{L}{2} \cdot f
$$


gde je:

$\sigma \quad$ napon pri zatezanju $\left[\mathrm{MN} / \mathrm{m}^{2}\right]$;

$\gamma_{\mathrm{m}} \quad$ zapreminska masa $\left[\mathrm{MN} / \mathrm{m}^{3}\right]$;

$\mathrm{L} / 2$ polovina dužine ploče $[\mathrm{m}]$;

f koeficijent trenja na kontaktu između betonske ploče i podloge (Tabela 1).
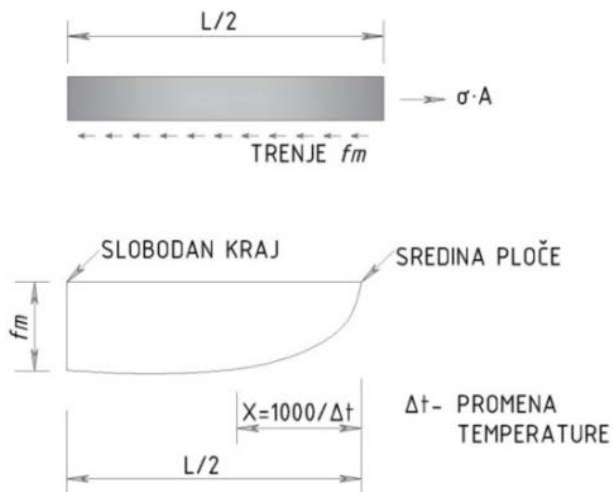

Slika 6. Naponi nastali pri skupljanju ploče [3]

Tačniji proračun, pomoću korigovanog koeficijenta trenja usled njegove nejednake angažovanosti po posmatranoj polovini ploče je [3]:

za $\mathrm{x}<\mathrm{L} / 2$

za $\mathrm{x}>\mathrm{L} / 2$

$$
f_{k}=f \cdot\left(1-\frac{2 \cdot x}{3 \cdot L}\right)
$$

$$
f_{k}=\frac{2 \cdot f}{3} \cdot \sqrt{\frac{L}{2 \cdot x}}
$$

Ako ploča ne bi imala spojnice, na dužini L bi došlo do pojave pukotina usled prekoračenja napona zatezanja. Usled skupljanja prirodni interval između pukotina iznosi oko $2 \cdot \mathrm{L}$, ali neposredno pri ugrađivanju, kada beton ima malu čvrstoću na zatezanje, pod uticajem temperature se mogu pojaviti pukotine na $6,5 \mathrm{~m}$. Zbog toga u roku od 16 časova po ugrađivanju betona spojnice moraju da budu isečene.

Oko deset puta je veća moć betona da „gura“ od sposobnosti da vuče. Ako beton ima čvrstoću na pritisak $20 \mathrm{MN} / \mathrm{m}^{2}$ u stanju je da gura oko $900 \mathrm{~m}$ kolovoza u oba smera od posmatrane tačke. Normalni interval između izdignutih ili teško izlomljenih spojnica iznosi od 1.800 do $2.750 \mathrm{~m}$ (čvrstoća na pritisak je $30 \mathrm{MN} / \mathrm{m}$ ). Naizmenični ciklusi do kojih dolazi svakog dana, „guranje“ $\mathrm{i}$ „vučenje“, izazivaju zamor ukoliko nastali naponi prevazilaze polovinu čvrstoće na zatezanje.

\subsection{Pritajeni naponi u betonu}

Ukoliko dođe do upadanja stranih materijala u spojnice, kao što su pesak, kamena sitnež, materijali koji se koriste u zimskom periodu za borbu protiv poledice i dr, sprečava se 
širenje ploča - projektovani zev se višestruko smanjuje. Zbog toga nastaju poprečne pukotine i lokalna oštećenja na ivicama spojnica.

\subsection{Termičke pukotine u svežem betonskom kolovozu}

Termičke pukotina u toku prvih nekoliko dana po ugrađivanju betona prvenstveno zavise od doba dana i godišnjeg doba; nakon toga zavise od dužine ploče i koeficijenta termičkog širenja agregata u mešavini. U svežem betonskom kolovozu nastaju sledeće pukotine:

- plastične pukotine, koje nastaju neposredno po ugrađivanju betona kao rezultat prevelikog isparavanja vode iz površine betona, naglog gubljenja vlage u donjoj zoni i zbog lošeg ugrađivanja finišerom;

- ljuspanje zastora, koje predstavlja niz malih nepravilnih pukotina;

- kontrakcione i vitoperne pukotine, koje nastaju u periodu očvršćavanja betona kao rezultat promene zapremine zbog variranja vlažnosti i temperature.

Najveće razlike između temperatura na gornjoj i donjoj površini betonske ploče su izmerene u betonu ugrađivanom u toku proleća i ranog leta, kada visoki intezitet radijacije sunca povećava temperaturu na donjoj površini.

Maksimalna srednja temperatura betona se javlja u kasno leto i ranu jesen, kada su istovremeno temperatura okoline, radijacija sunca i temperatura podloge na visokom nivou. Opasnost od termičkih pukotina u svežem nearmiranom betonskom kolovozu može da se izrazi koeficijentom loma [3]:

$$
C_{F}=\frac{T_{0}}{T_{L}}=\frac{\left(R_{S} T_{1}+R_{w} T_{w}+R_{i} T_{i}\right)}{T_{L}}
$$

gde je:

$\mathrm{C}_{\mathrm{F}} \quad$ koeficijent loma;

$\mathrm{T}_{0} \quad$ efektivna promena temperature koja se dobija proračunom međusobno zavisnih temperatura u vreme očvršćavanja betona $\left[{ }^{\circ} \mathrm{C}\right]$;

$\mathrm{T}_{\mathrm{L}} \quad$ granična promena temperature $\left[{ }^{\circ} \mathrm{C}\right]$;

$\mathrm{T}_{1} \quad$ srednja temperatura $\mathrm{u}$ betonskoj ploči koja utiče na podužno širenje ili skupljanje ploče; ovom kretanju se suprotstavlja trenje između ploče i podloge $\left[{ }^{\circ} \mathrm{C}\right]$;

$\mathrm{T}_{\mathrm{w}} \quad$ razlika u temperaturi na površini i dnu betonske ploče, koja prouzrokuje njeno savijanje ili izvijanje $\left[{ }^{\circ} \mathrm{C}\right]$;

$\mathrm{T}_{\mathrm{i}} \quad$ nelinearna promena temperature po dubini ploče koja izaziva napone kao rezultat različitog zapreminskog širenja pojedinih delova unutar ploče $\left[{ }^{\circ} \mathrm{C}\right]$;

$\mathrm{R}_{\mathrm{S}}, \mathrm{R}_{\mathrm{w}}, \mathrm{R}_{\mathrm{i}}$ koeficijenti koji ograničavaju podužno pomeranje ploča preko podloge, savijanje i unutrašnje napone zbog promene zapremine (Tabele 3. i 4) [6,7].

Teorijski, betonska ploča bi trebalo da pukne ako je $\mathrm{C}_{\mathrm{F}}>1$. Međutim tu treba razlikovati veoma uzane pukotine u blizini površine i velike pukotine koje se pružaju kroz celu ploču (u ovom drugom slučaju $\mathrm{C}_{\mathrm{F}}>1,5$ ).

Za kolovoze kod kojih se na svakih približno 6,0 m nalaze poprečne spojnice treba usvojiti $\mathrm{R}_{\mathrm{S}}=0, \mathrm{R}_{\mathrm{w}}=0,5 \mathrm{i} \mathrm{R}_{\mathrm{i}}=1$, dok se kod armiranih kolovoza sa razmakom spojnica od oko $30 \mathrm{~m}$ usvaja $R_{S}=0,1$ i $R_{W}=R_{i}=1$. 
Za graničnu promenu temperature $\mathrm{T}_{\mathrm{i}}$ treba usvojiti:

- $5^{\circ} \mathrm{C}$ za betone koji sadrže kvarcni agregat;

- $8^{\circ} \mathrm{C}$ za betone koji sadrže granitni agregat;

- $15^{\circ} \mathrm{C}$ za betone koji sadrže krečnjački agregat.

Tabela 3. Koeficijenti kojima podloga ograničava kretanje ploče [3]

\begin{tabular}{|c|c|c|c|}
\hline \multirow{2}{*}{$\begin{array}{l}\text { dužina ploče } \\
{[\mathrm{m}]}\end{array}$} & \multirow{2}{*}{$\begin{array}{l}\text { modul elastičnosti } \\
{\left[\mathrm{N} / \mathrm{mm}^{2} \cdot 10^{4}\right]}\end{array}$} & \multicolumn{2}{|c|}{ koeficijent ograničavanja podloge $R_{s}{ }^{*}$} \\
\hline & & $\begin{array}{l}\text { koeficijent trenja } 1,0 \mathrm{za} \\
\text { pomeranje od } 5,1 \mathrm{~mm}\end{array}$ & $\begin{array}{l}\text { koeficijent trenja } 2,0 \mathrm{za} \\
\text { pomeranje od } 0,76 \mathrm{~mm}\end{array}$ \\
\hline 30 & $\begin{array}{l}2,1 \\
3,4\end{array}$ & $\begin{array}{l}0,04-0,05 \\
0,02-0,03\end{array}$ & $\begin{array}{l}0,13-0,23 \\
0,08-0,14\end{array}$ \\
\hline 60 & $\begin{array}{l}2,1 \\
3,4\end{array}$ & $\begin{array}{l}0,10-0,15 \\
0,06-0,09\end{array}$ & $\begin{array}{l}0,26-0,48 \\
0,16-0,30\end{array}$ \\
\hline 150 & $\begin{array}{l}2,1 \\
3,4\end{array}$ & $\begin{array}{l}0,30-0,48 \\
0,18-0,31\end{array}$ & $\begin{array}{l}0,66-0,98 \\
0,40-0,74\end{array}$ \\
\hline 300 & $\begin{array}{l}2,1 \\
3,4\end{array}$ & $\begin{array}{l}0,60-0,95 \\
0,38-0,64\end{array}$ & $\begin{array}{c}1,0 \\
0,79-1,0\end{array}$ \\
\hline
\end{tabular}

*sračunato za slobodno termičko dilatiranje $120-240 \cdot 10^{-6}$

Tabela 4. Koeficijenti koji ograničavaju savijanje (izvijanje) [3]

\begin{tabular}{|c|c|c|c|c|}
\hline \multirow{2}{*}{$\begin{array}{c}\text { dužina ploče } \\
{[\mathrm{m}]}\end{array}$} & modul elastičnosti & \multicolumn{4}{|c|}{ koeficijent ograničavanja savijanja $\mathrm{R}_{\mathrm{w}}{ }^{*}$} \\
\cline { 3 - 5 } & {$\left[\mathrm{N} / \mathrm{mm}^{2} \cdot 10^{4}\right]$} & \multicolumn{3}{|c|}{ modul reakcije tla $\left[\mathrm{N} / \mathrm{mm}^{3}\right]$} \\
& & 0,0271 & 0,109 & 0,191 \\
\hline \multirow{2}{*}{6,6} & 2,1 & $0,53-0,70$ & $0,58-0,80$ & $0,65-0,88$ \\
& 3,4 & $0,32-0,48$ & $0,38-0,59$ & $0,40-0,64$ \\
\hline \multirow{2}{*}{7,6} & 2,1 & $0,80-0,95$ & $0,88-1,00$ & $0,94-1,00$ \\
& 3,4 & $0,51-0,73$ & $0,60-0,85$ & $0,63-0,92$ \\
\hline \multirow{2}{*}{9,1} & 2,1 & 1,0 & 1,0 & 1,0 \\
& 3,4 & $0,77-1,00$ & $0,84-1,00$ & $0,90-1,00$ \\
\hline
\end{tabular}

\subsection{Termičke pukotine u zastoru fleksibilnih kolovoznih konstrukcija}

Pri niskim temperaturama (manjim od $-15^{\circ} \mathrm{C}$ ) mogu da se pojave poprečne pukotine zbog pojave termičkih napona koji prevazilaze čvrstoću na zatezanje. Kritični modul krutosti mešavine pri dužini trajanja opterećenja od 30 minuta iznosi $2 \cdot 10^{5} \mathrm{~N} / \mathrm{m}^{2}$, a za bitumen $10^{9} \mathrm{~N} / \mathrm{m}^{2}$. U zavisnosti od penetracije bitumena na $25^{\circ} \mathrm{C}$ i $5^{\circ} \mathrm{C}$, sa dijagrama na Slici 7 . mogu da se odrede kritične temperature za pojavu pukotina [3].

Eksperimentalno utvrđeni koeficijenti termičkog skupljanja asfalt betona pri kritičnim temperaturama se kreću od 2,07 do $2,58 \cdot 10^{5} /{ }^{\circ} \mathrm{C}$.

Termički izazvani naponi se mogu približno odrediti pomoći dijagrama Kristisona prikazanog na Slici 8. Ako termički izazvani naponi prelaze 1,4 MPa postoje uslovi za pojavu pukotina i treba pristupiti detaljnijim analizama. 


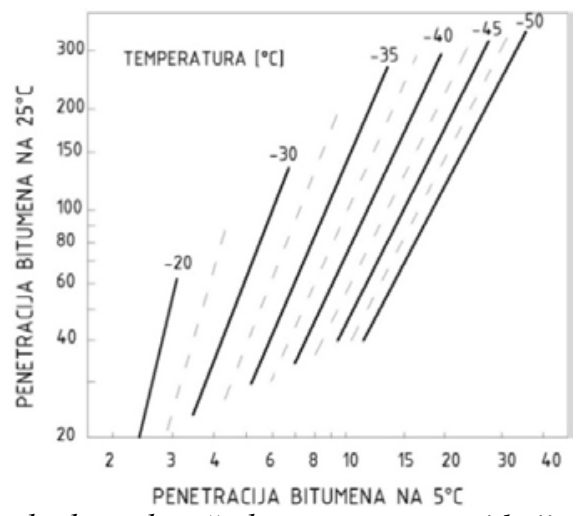

Slika 7. Dijagram za predviđanje kritičnih temperatura pri kojima se pojavljuju termičke pukotine [3]

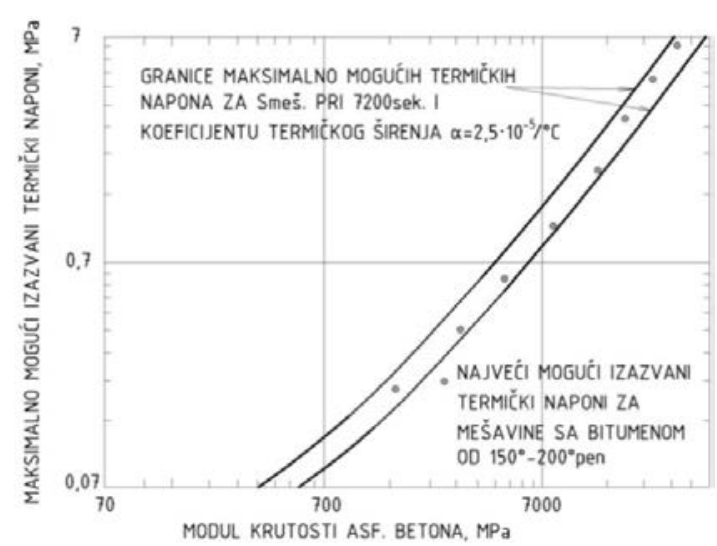

Slika 8. Termički izazvani naponi u zavisnosti od modula krutosti mešavina [3]

\subsection{Kontrola pukotina}

Da bi se uslovi za pojavu termičkih pukotina sveli na što manju meru prvenstveno treba obratiti pažnju na osobine bitumena i debljinu sloja od asfalt betona.

$\mathrm{U}$ principu treba primenjivati mekše bitumene penetracije 150 do $200^{\circ} \mathrm{C}$ pen. Dodatkom azbestnog filera se znatno smanjuje broj termičkih pukotina (i do 50\%). Granične vrednosti modula krutosti mešavina za različite temperature su prikazane u Tabeli 5.

Tabela 5. Maksimalne vrednosti modula krutosti [2]

\begin{tabular}{|c|c|c|}
\hline \multirow{2}{*}{$\begin{array}{c}\text { minimalna temperatura } \\
\text { na } 5 \text { cm dužine }\end{array}$} & \multicolumn{2}{|c|}{ modul krutosti $S_{\text {meš }}[\mathrm{MPa}]$} \\
\cline { 2 - 3 } & očekivane pukotine & eleminisane pukotine \\
\hline$-40^{\circ} \mathrm{C}$ & 7.000 & 2.800 \\
\hline$-32^{\circ} \mathrm{C}$ & 4.900 & 2.100 \\
\hline$-23^{\circ} \mathrm{C}$ & 2.800 & 1.400 \\
\hline$-12^{\circ} \mathrm{C}$ & 700 & 350 \\
\hline
\end{tabular}


Minimalna potrebna debljina zastora da bi se sprečila pojava termičkih pukotina po Hajeku i Hasu [8] se može očitati sa dijagrama sa Slici 9. Na dijagramu se vidi da je dominantan uticaj konzistencije bitumena. "Indeks pukotina” na Slici 9. se definiše kao ukupan broj pukotina po jednoj traci, uvećan za pola na dvosmernom putu sa ukupno dve trake.

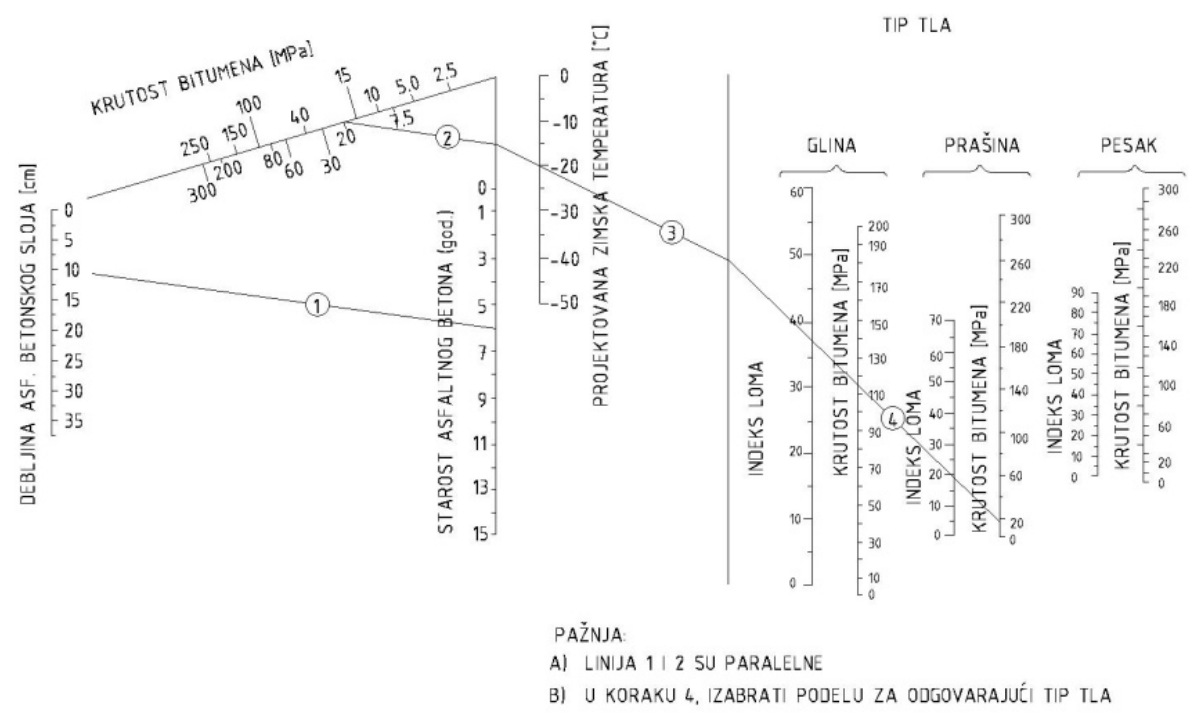

Slika 9. Dijagram za predviđanje pukotina na niskim temperaturama [3]

\subsection{Superpozicija napona kod krutih kolovoznih konstrukcija}

Pored napona od opterećenja vozila, trebalo bi pri dimenzionisanju analizirati i napone od temperature, jer ovi drugi mogu biti istog reda veličine, a ponekad i veći.

Pri dimenzionisanju, odnosno određivanju debljine kolovozne konstrukcije, samo metoda konačnih elemenata može direktno da uzme u obzir i napone usled temperature. Generalno važi princip da spojnice i armatura preuzimaju brigu o termičkim naponima, a debljina konstrukcije zavisi samo od opterećenja [9].

Međutim, suprotno tome je mišljenje da treba uzeti u obzir i termičke napone. Sa gledišta uticaja na debljinu betonske ploče (pored opterećenja) od termičkih napona ima smisla analizirati napone pri savijanju i izvijanju. U prilog ovog drugog stava, govori i dijagram na Slici 10. Prikazani su naponi od savijanja (za ploču debljine $25 \mathrm{~cm}$ ) u letnjem periodu, pri maksimalnoj amplitudi temperature na površini ploče i to u ranim jutarnjim časovima, a nešto manji naponi na dnu ploče na početku popodneva. Amplituda napona na površini ploče malo zavisi od debljine ploče, a na dnu je njena zavisnost još manja.

Naponi od trenja su, kod nearmiranih ploča dužine od $6,0 \mathrm{~m}$, praktično zanemarljivi i smanjuju dejstvo napona od savijanja (rano ujutru i rano popodne). U toku noći naponi od opterećenja i temperature su suprotnog dejstva i ne mogu biti uzrok pukotina u očvrslom betonu. Posle podne se naponi od temperature superponiraju sa naponima od opterećenja i moraju se uzeti u obzir pri analizi ponašanja kolovoza. 


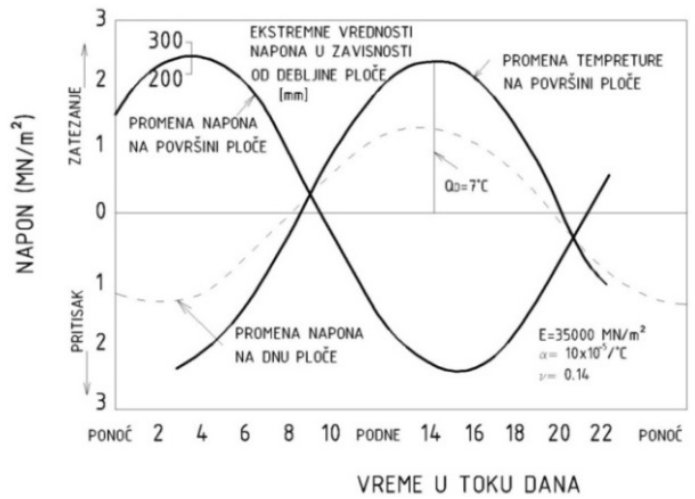

Slika 10. Promena kombinovanih termičkih napona u toku dana [3]

\section{UTICAJ SREDINE U DIMENZIONISANJU KOLOVOZNIH KONSTRUKCIJA}

Uticaj sredine se kod dimenzionisanja kolovoznih konstrukcija uobičajeno uzima u obzir preko dejstva mraza i bubrenja tla u posteljici.

Uticaj bubrenja tla na opadanje upotrebljivosti se određuje preko: konstante bubrenja, mogućeg vertikalnog izdizanja i verovatnoće bubrenja. Moguće vertikalno izdizanje predstavlja vertikalno izdizanje tla u posteljici pod ekstremnim uslovima bubrenja (koji se javljaju kada je visoka vlažnost i plastičnost). Do te vrednosti se može doći laboratorijskim putem, empirijski, ali vrednost može biti i usvojena. Verovatnoća bubrenja predstavlja deo (izražen u procentima) od projektovane deonice puta, na kojoj može da dođe do bubrenja. Za određenu deonicu se smatra da je verovatnoća bubrenja $100 \%$ ako je indeks plastičnosti tla u posteljici veći od 30 i debljina sloja veća od $60 \mathrm{~cm}$.

Fenomen izdizanja tla zbog dejstva mraza po efektima je dosta sličan bubrenju. Izdizanje nastaje kada se slobodna voda u posteljici skupi, smrzne i formira ledeno sočivo. Tri osnovna parametra preko kojih je definisano izdizanje usled mraza su: konstanta izdizanja, maksimalni mogući gubitak upotrebljivosti i verovatnoća izdizanja. Verovatnoća izdizanja zbog dejstva mraza predstavlja procenat od posmatrane površine na kojoj može da se javi oštećenje. Ona zavisi od osetljivosti na mraz, vlažnosti, odvodnjavanja, trajanja temperature ispod nule i broja ciklusa mržnjenja i otapanja. Za sada ne postoji tačan kriterijum za izbor verovatnoće izdizanja. To ocenjuje sam projektant.

\section{SUPERPAVE SISTEM ZA PROJEKTOVANJE BITUMENOM VEZANIH MATERIJALA}

Istraživanja u SAD, sa ciljem dobijanja dugotrajne kolovozne konstrukcije, dovela su do otkrića sistema SUPERPAVE [10]. Pored proučavanja individualnih svojstava i karakteristika materijala u različitim kombinacijama, testirana je i izdržljivost usled opterećenja i temperature, zbijanja i izgradnje, da bi se utvrdilo kako što duže održati kolovoznu konstrukcijusa svojim glavnim karakteristikama. Ova istraživanja su stvorila 
mogućnost da se predvide temperaturni uslovi i vlažnost u kolovoznoj konstrukciji, što je čini specifičnom, dugotrajnom i otpornom na uticaje prirodne sredine.

Tako je nastao sistem SUPERPAVE (SUperior PERforming asphalt PAVEments) u okviru strateškog programa istraživanja u oblasti puteva (Strategic Highway Research Program-SHRP, 1987-1993) koji je namenjen za projektovanje asfaltnih mešavina spravljanih po vrućem postupku (Superpave Hot Mix Asphalt-SHMA) sa maksimalnom veličinom zrna 9,5 - 12,5 - 19,0 - 25,0 - 37,5mm.

Cilj sistema SUPERPAVE je da se definišu karakteristike veziva i agregata i njihov optimalni odnos, na osnovu čega može da se predvidi ponašanje bitumenom vezanih materijala u slojevima kolovozne konstrukcije u fazi eksploatacije, kao i da se razviju postupci za pouzdano merenje tih karakteristika. Njegova prednost u odnosu na ranije primenjivane postupke je u merenju i povezivanju reoloških karakteristika mešavine sa ponašanjem kolovozne konstrukcije u fazi eksploatacije.

Najbitnija karakteristika SUPERPAVE sistema je da se za kriterijume pri izboru projektovane mešavine koristi osnovni kvalitet materijala koji ulaze u sastav mešavine i međusobni odnos karakteristika koje zavise od prirodne sredine i opterećenja. Druga karakteristika su kriterijumi za projektovanje bitumenom vezanih mešavina zasnovani na ponašanju ugrađenih mešavina (dubina kolotraga, površina zahvaćena pukotinama od zamora i pukotinama od niskih temperatura nastalih u okviru projektnog perioda). Treća karakteristika je određivanje kvaliteta kolovoza na osnovu međusobnog odnosa kolovozne konstrukcijespravljene od asfaltne mešavine, saobraćaja i sredine.

\section{ZAKLJUČAK}

Materijali u kolovoznoj konstrukciji se u toku dana različito zagrevaju i hlade. Naprezanje u kolovoznoj konstrukciji pri cikličnoj promeni temperature nastaje kao direktna posledica promene zapremine kojoj su podložni svi materijali, čemu dodatno doprinosi međusobna povezanost svih slojeva. Ako su ta naprezanja toliko velika da materijali nisu u mogućnosti da ih podnesu, dolazi do štetnih pojava u kolovoznoj konstrukciji, pukotina ili deformacija. Evidentno, potrebno je projektovati kolovoznu konstukciju koja će se odupreti takvim uticajima.

Međutim, najveća oštećenja u određenim slučajevima mogu izazvati niske temperature u kolovoznoj konstrukciji, što je povezano sa prisutnošću vode u zoni kolovozne konstrukcije.

SUPERPAVE sistem je stvorio mogućnost da se projektuje i izgradi takva kolovozna konstrukcija koja će se dugotrajno odupreti svim uticajima (ili većini uticaja) spoljašnje sredine i tokom to perioda neće bitno menjati sopstvene karakteristike.

\section{LITERATURA}

[1] Babić, B., Projektiranje kolničkih konstrukcija, Hrvatsko društvo građevinskih inženjera, Zagreb, 1997.

[2] Cvetanović, A., Banić, B., Kolovozne konstrukcije, Akademska misao, Beograd, 2007.

[3] Cvetanović, A., Kolovozne konstrukcije, Naučna knjiga, Beograd, 1993. 
[4] Haas, R., Hudson, W.R., Zaniewski, J., Modern Pavement Management, Krieger Publishing Company, Malabar, Florida, 1994.

[5] Road Note 29, A Guide to the Structural Design of Pavements for New Roads, Road Research Laboratory, London, 1970.

[6] Friberg, F., Restrained Temperature Movements in Long Slabs,ACI, Vol. 60, 1968.

[7] Sperkes, N., Stresses in Concrete Road Slabs, The Structural Engineer, 1939.

[8] Hajek, J., Haas, R., Predicting Low-Temperature Cracking Frequency of Asphalt Concrete Pavaments, Hughway Research Record, No. 407, 1972.

[9] Joder, E.,Witczak, M., Principles of Pavement Design, John Wiley \& Sons Inc., New York, 1975.

[10] Transportation Research Board, Superpave-Performance by Design, Washington, D.C., 2005.

\section{STRESSES AND STRAINS IN PAVEMENT STRUCTURES DUE TO THE EFFECT OF TEMPERATURES}

Summary: At its absolute amount, stresses due to the effect of temperature in the pavement structures, especially those rigid, are often of the same order of magnitude as those resulting from vehicles' load, but it happens that due to such impact many slabs become cracked before the road is handed over into operation. The temperature stresses which occur in pavement structures include stresses due to bending and buckling, stresses due to friction and hidden stresses. Stresses caused by the influence of temperature in the pavement structure during the day are generally below the strength of the component materials so they do not cause the consequences for structure. However, appearance of residual stresses and their accumulation after a sufficiently long period of time may lead to failure in structure, i.e. thermal fatigue. The paper presents the effects of temperature changes on the pavement structures in the physical and mechanical terms, and the manner in which the temperature is taken into account during the design of pavement structures.

Keywords: pavement structure, temperature, temperature stresses, design 